\title{
The School Library: Interdisciplinary, Collaborative, Virtual
}

\author{
David V. Loertscher, Professor \\ School of Library and Information Science \\ San Jose State University \\ Blanche Woolls, Professor Emerita \\ School of Library and Information Science \\ San Jose State University
}

The school library today, if it is to function in a digital age, must adopt to different ways to provide information to students. The school library and the school librarian much change.

\section{The Chill of Change}

To many, one of the most chilling words in English has only six letters, change. To change means to do something differently, and that new way may be unfamiliar and even unknown or not understood. The patterns of the past are remodeled if not thrown out totally. It is sometimes done before one feels any change is needed, or, even if something appears not to be working as well as it should, it isn't working all that badly. Sometimes it is unclear what to do to change to make it work better. Robinson talks about three simple words, "The $3 \mathrm{Cs}$ of life; you must make a choice to take a chance or your life will never change."i In the fast-paced world of the twenty-first century, no new choices and no new chances is not an option.

Our school libraries are in need of restructuring, in need of changing, and this paper is going to help you understand some possible changes so that you can take a chance and choose them yourself rather than have something very different thrust upon you by someone else. The premise is the depth of digital.

\section{The Depth of Digital}

It would be very difficult to engage in a debate between digital and traditional if you were on the side of traditional. The speed with which cell phones become obsolete may be the most 
telling factor. We live in a digital age with phones that now allow us to do much more than simply call our friends. We now can text our colleagues, send instant photos of what we are planning to eat for lunch or ask if a coat we are considering buying is the right color or style. We can pay our bills, manage our bank accounts, buy tickets to concerts and sporting events, read books and newspapers, watch movies, and guide our cars. Best of all, we can look up "things" like the location of Qatar and its capital, religion, and population. To think that the depth of digital in our world will not affect our libraries is the worst case of an ostrich burying its head in the sand. What it does is make us recognize the importance of being creative in our libraries and allowing others to be creative there also.

\section{The Creativity of a Commons}

Two authors, Kim and Coxon defined creativity as "making or doing something useful that is original or better." create something new in the world. Creativity comes into play wherever you have the opportunity to generate new ideas, solutions, or approaches,"iv and they provide suggestions for helping others build creative confidence, "a way of experiencing the world that generates new approaches and solutions.", Their steps include:

- Flip: from Design Thinking to Creative Confidence

- Dare: from Fear to Courage

- Spark: From Blank Page to Insight

- Leap: From Planning to Action

- Seek: From Duty to Passion

- Team: Creatively Confident Groups

- Move: Creative Confidence to Go ${ }^{\mathrm{vi}}$ 
These will be expanded later; here begins "choice," a choice many school librarians are implementing.

Some school librarians have chosen to turn their "useful" libraries into something better, expanding their efforts to provide information for teachers and students; they have created a learning commons. From the beginning,

Teacher librarians who were rethinking the idea of "commons" and making "learning" the central focus of their program expressed their excitement and realization that they were making a major step into a new concept of the role of the library from the storage of knowledge to the creation of knowledge. They also began to realize that the learning commons could be the major bridge in the schools between formal and informal learning. ${ }^{\text {vii }}$

Librarians are creating a facility with a "completely flexible learning space where neither computers nor books get in the way." ${ }^{\text {viii }}$ This open, flexible space is created by teachers, staff and students and any interested members of the community who may serve as volunteer learning specialists. The policies and behavior guidelines for the use of the space are developed by the students themselves to provide a "collegial social environment," a social environment encouraging creative experiences for individual students, but, most importantly, for groups of students who will work together to problem solve. These open spaces allow students to connect and create. To get a better feel for the change from library to learning commons, see this brief video interview of David Loertscher and Carol Koechlin at: http://preview.tiny url.com/zxf2ajt.

\section{The Connectivity of a Commons}

Two concepts of the commons are in place to "connect" learners. The first is a major shift in collection development from a more traditional approach; the second is the concept of group work or connections among learners. 
The more traditional idea of collection development was to create an extensive resource of physical items that would be owned by the library and circulated to students and teachers. In today's world however, the trend is toward a new type of "connection development," providing patrons a limited set of materials but to open the the collection to Open Educational Resources (OeRs). For example, a study of medieval art would not be limited to a few art books with reproductions, but a connection to major museums and galleries throughout the world where medieval paintings could be studied and used essentially for free. In addition, the concept of user driven collection development would mean that students and teachers would assist the librarian in building the connections of the library's physical collection with OERs that would enhance particular content investigations. Such a concept turns the collection from a single selector into a participatory curation culture. Many librarians use software such as LibGuides or free tools such as Google Sites or Google Docs to collaboratively build topical OER collections. In creating the connections part of the collection, suddenly that part of the collection becomes accessible 24/7 and on any device owned by the users. Librarians in third world nations could, with the help of their users, develop huge online libraries in most any language. To these free resources, the librarian adds fee based resources such as databases and copyrighted ebooks as local budgets can afford. However, most librarians might concentrate first on OER connection development and then add collection development on top: the flipped collection.

An example of an entire course of study that uses OERs almost entirely is the California History for Kids Grade 4 project produced by graduate students at the School of Information of San Jose state University under the direction of Professor Loertscher. It can be seen at: https://sites.google.com/site/cahistoryforkidsgr4/ and consists of resources, ideas for study, sample downloadable lesson plans and is directed at the students themselves with information 
for the teachers in the background. What makes the site unique is its participatory nature.

Students, teachers, and teacher librarians are encouraged to share resources and upload their work so that it can be shared across schools and across the state of California. Some thirty masters level students were involved in the project suggesting that groups of teachers and teacher librarians anywhere might join forces to provide equitable and free learning experiences to every learner who has a device and connection to the Internet.

The second concept of connection is through the opportunities for students to interact with group experiences. Todd and Dadlani, in reporting the findings of their study of research and writing processes of high school students in a school library found that

Having completed the group task, students identified the mutuality of working to a common goal and the stronger relationships among them that it fostered: "I love working in group projects because you have friends who help you get to your goal." Mutuality developed stronger collegial relationships amongst a number of the students and taught important interpersonal skills. ${ }^{\text {ix }}$

Connectivity called mutuality by Todd and Dadlani provides students with opportunities to develop the interpersonal skills they will need to work in groups in their future workplaces. Others who learn connection skills are the teachers who will not only become more aware of the curriculum being taught in other classrooms but they will see what can be used to make learning more meaningful for all students, to move beyond the limits of the closed classroom. It sets up the path to collaboration.

\section{The Collaboration of a Commons}

Collaboration begins with the teachers who can model it for their students. Collaboration means all the teachers and that includes those "special" teachers who are always so vulnerable when positions are cut: school librarians, technology specialists, reading specialists, art, music, 
and physical education teachers, counselors and the school nurse. The Commons brings them together into a working environment that expands individual classroom learning. A community expert could be asked to present to a wider audience. The counselor explains both the practice software available for students to take the PSAT test encouraging teachers to have all their students participate so they can consider education beyond high school.

Collaboration moves the curriculum into something that is more recognizable to students; offering information and experiences they will need in their real world rather than unrelated lessons that seem to have little relationship after they leave the school for the day. While trying to do this for every curriculum unit in every classroom is not possible, collaboration can allow even brief assignments that offer students a chance to work in an open singly or in groups in a non-threatening environment with the materials and equipment needed to create or invent. That is called a makerspace.

Making a Makerspace

The means of creating makerspaces has been covered extensively in the literature, and a bibliography is found in Appendix A. These may be designated spaces within the Commons or they may be moveable and can be moved at any location within the Commons or even taken to a classroom. These are designed to include Kelly and Kelly's previously mentioned steps.

Flip: from Design Thinking to Creative Confidence predicts that "a creative mindset can be a powerful force for looking beyond the status quo."x Makerspaces offer the ability to work to demonstrate an assignment or to move beyond the original assignment into new thinking.

Makerspaces provide opportunities for students to Dare and change from Fear to Courage. "Fear of failure holds us back from learning all sorts of new skills, from taking on risks, and from tackling new challenges." $\times$ i Working in a makerspace allows students to own failures so 
they can learn from it. They can "figure out what went wrong and what to do better the next time"xii with no penalty.

In discussing "Spark: From Blank Page to Insight" Kelly and Kelly suggest that helping students with their creative confidence gives them "The creative spark needed to come up with new solutions is something you have to cultivate, over and over again."xiii The ability to create in a makerspace builds confidence.

The use of a makerspace to create a prototype helps students "Leap: From Planning to Action." "The reason for prototyping is experimentation - the act of creating forces you to ask questions and make choices. It also gives you something you can show to and talk about with other people."xiv The authors also encourage students to Seek, moving From Duty to Passion "To make the leap from inspiration to action, small successes are the key."xv Makerspaces allow for small successes that can build into larger successes. Finally, they talk about the Team: to build Creatively Confident Groups. It is their belief that working in teams helps tap the creative in all students. ${ }^{\mathrm{xvi}}$

Most examples in the literature describe a physical space stocked with tools and resources to which students come. However, another group of San Jose State University students took the concept and made the idea of making and makerspaces into the virtual world. They created A Virtual Makerspace using the free software of Symbaloo to link students $24 / 7$ to virtual tools that allow them to build, create, invent, and share their creativity as makers. This novel idea can be seen, downloaded, and adapted for any school anywhere is at:

http://www.symbaloo.com/mix/virtualmakerspace and contains webmixes for the various levels from K-12 and on to adults. Clicking on any letter at the top of the screen, "MAKING," will send the user to the rationale, criteria for selection of tools, and how to download and use the 
entire webmix, plus, suggestions for tailoring the various tools to the enormous differences in accessibility by local schools by tech directors.

\section{The Virtual Version}

A virtual makerspace may reside in a Virtual Learning Commons ${ }^{\mathrm{x} v i i}$ as defined by Loertscher et al. The authors defined the VLC:

The Virtual Learning Commons (VLC) is the online force of the Learning Commons, a digital learning community in which the whole school participates. It is not a library website which only provides a one-way stream of useful information. Instead, both the instructors and the students of the school collaborate to establish the VLC as a place where individuals and groups are actively learning, communicating, and building together in real time. This participatory community of learners is powered by software, which allows many contributors, and it is as public or private as the school wishes it to be. ${ }^{x \text { vii }}$

The idea stemmed from the question: "How can the library move into the center of teaching and learning rather than being peripheral to it?" And, if this virtual place was really to compete with the Internet and social media, how would it be constructed to be a truly participatory culture?

Fortunately, free and ubiquitous technologies now exist that make a participatory culture possible across the various devices available in the school and in the hands of students and teachers. In other words, a technology had to exist that would be at the fingertips of each user and available $24 / 7$ if it had any possibility to compete in a crowded information world.

One early tour of a real VLC is instructive. How it actually works is found in the following example by a teacher librarian and followed by a longer interview and description of the possibilities. Please view The Virtual Learning Commons by Julie Chambers at: http:/tinyurl.com/n5tk46b. Another

In order to help practitioners across the world create a virtual learning commons, the graduate students in the school of Information at San Jose State University worked 
with Dr. Loertscher to create three major templates that can be downloaded and used by individual schools as the starter design of what a participatory learning community looks like, and contains. These templates are as follows:

- Elementary school: https://sites.google.com/site/templatevlcelementary

- Middle school: https://sites.google.com/site/templatevlcmiddle

- High School: $\underline{\text { https://sites.google.com/site/templatevlchigh }}$

Each of the templates contains various rooms where literacy activities, inquiry, school culture and other activities are happening. Again, the concentration is on a system where both adults and students of all ages are participating and contributing. Teacher librarians who pull down these templates can change any of the rooms and use or create activities and information spaces on their own rather than just duplicating the spaces created by the original authors. As the idea catches on to the entire school, other technologies and structures can be built for the individual school as a reflation of their own unique learning culture.

\section{Conclusion}

The potential of the library learning commons to become the center of teaching and learning in the school is central to the concept of this paper. To remain known as a repository of printed books that circulate and are protected by a "librarian" is not a supportable entity for any school in the $21^{\text {st }}$ century. As the Internet continues to connect the last billion people on the planet, new ideas about the library concept must emerge.

This paper has outlined several attempts to explore a new library learning commons concept, to overcome the chill of change. We invite you to test the creativity, connectivity, and collaboration of the Learning Commons. To the leadership of the international community of 
scholars in IASL, we as authors issue this challenge: If you find the ideas in this paper wanting, create an alternative view of the possible; both now and the future. Every passing year when libraries essentially remain the same is one more opportunity for others to reinvent another concept that puts us as a profession out of business. Change now.

Left this in if you want to include it:

\section{An interview about the Learning commons with Steve Hargadon and David Loertscher at: http://tinyurl.com/zrp7ecm}

\footnotetext{
${ }^{i}$ Robinson, Shannon, "Choices, Chances, et Changes," Teacher Librarian (June 2013): 25.

${ }^{i i}$ Kim, Kyung H. and Stephen V. Coxon, "The Creativity Crisis, Possible Causes, and What School Can Do," in Jones, Jami and Lori J. Flint, eds. The Creative Imperative: School Librarians and teachers Cultivating Curiosity Together. Santa Barbara, CA: Libraries Unlimited, 2013. p. 53.

iii Tom Kelly and Kelley, David. Creative Confidence: Unleasing the Creative Potential within All of Us. New York: Crown Business, 2013.

${ }^{\text {iv } I b i d ., \text { p. } 3 .}$

${ }^{v}$ Ibid., p. 7.

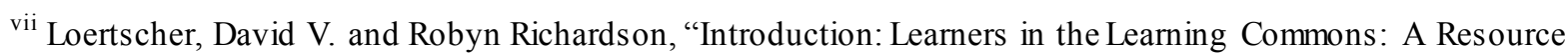
Treasury," in Loertscher, David V., ed. Partners in the Learning Commons: Papers of the Treasure Mountain Research retreat \#19 November 13-14- Hartford, CT. Salt Lake City, Utah: Learning Commons Press, 2013. p. vivii

viii Loertscher, David V. et al. The New Learning Commons Where Learners Win!, $2^{\text {nd }}$ ed. Salt Lake City, Utah: Learning Commons Press, 2011: p. 11.

${ }^{i x}$ Todd, Ross J. and Punit Dadlani, "Collaborative Inquiry in Digital Information Environments: Cognitive, Personal and Interpers onal Dynamics," in Loertscher, David V., ed. Partners in the Learning Commons: Papers of the Treasure Mountain Research retreat \#19 November 13-14-Hartford, CT. Salt Lake City, Utah: Learning Commons Press, 2013. p. 11.

${ }^{\mathrm{x}}$ Kelly and Kelly, Op sit., p. 18.

${ }^{x i}$ Ibid., p. 44.

xii Ibid., p. 51

xiii Ibid., p. 74.

${ }^{\text {xiv }}$ Ibid., p. 130.

${ }^{\mathrm{xv}}$ Ibid. p. 168.
} 
xvii Loertscher, David V., Carol Koechlin, and Sandi Zwaan. The Virtual Learning Commons. Learning Commons Press, 2012.

xviii Ibid., p. 2. 